\title{
Start-Up Investor Governance Case
}

\author{
by Robert M. LoBue \\ (Germany)
}

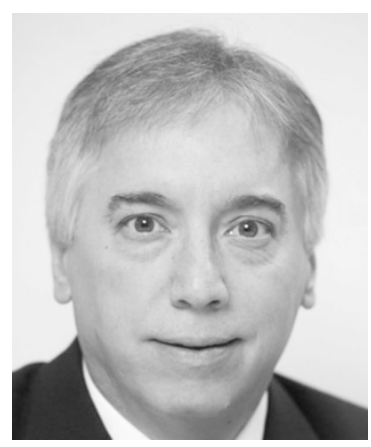

ESB Business School, Reutlingen University, Reutlingen, Germany International Center for Corporate Governance, University of St. Gallen, St. Gallen, Switzerland

It was not until the early 1990s that the Mosaic internet browser made the World Wide Web broadly available to individuals, while in the preceding decade, an innovative California-based start-up designed and sold networking software that was used by large information technology (IT) installations to connect and communicate through the internet. In the classic Silicon Valley start-up manner, the founders of the company had raised money for investment from a United States (US)-based venture capital firm. They also implemented an employee stock option plan (ESOP) as a compensation incentive for the company's employees. As the company had achieved early US and international sales successes, the founders established wholly owned sales and service subsidiaries in Europe, and they also raised capital, less traditionally, from a United Kingdom (UK)-based unit trust.

But by the early 1990s, the founders ran into a serious rough patch in meeting their goals for financial results as well as for the quality of their financial reporting disclosures. They lost the confidence of the board of directors, and the board replaced the founding executives with seasoned industry managers. The new executive team was tasked by the board with three key parallel strategic objectives:

1. Restarting the company to return it to its innovative roots and to operating profitability

2. Sourcing new venture capital to back their new strategy

3. Leading an initial public offering (IPO), the ultimate Silicon Valley start-up experience 
Due to the company's financial difficulties, however, the ownership value of its private shares was significantly reduced to just pennies per share. This was much lower than the value the UK unit trust had paid for the shares in its block. In restructuring the company's equity, its old shares were replaced through a reverse stock split. Apparently, this contributed to a local legal imperative that required the trustee to directly distribute the shares of the software company previously held institutionally by the trust to the many individual investors in the trust, though the trustee did remain as investment advisor to these shareholders. On top of this, dozens of employees had left the company, and some of them had exercised their right to purchase the option shares that had vested to them in the ESOP. This led to the unique situation that a small Silicon Valley software start-up with just over 100 employees and less than US\$30 million in annual sales found itself with close to 300 external individual shareholders.

A critical corporate governance risk came into play that threatened the company's ability to achieve its new mission. The Securities and Exchange Commission (SEC) of the US government serves to protect the rights of smaller investors from expropriation and fraud by unscrupulous company founders and overpowerful managers and majority owners. When start-up founders solicit an individual citizen for direct sale of shares in a private corporation, they must collect evidence that the buyer earns a relatively high annual income or possesses a substantial value of overall wealth according to SEC regulations (which are similar to the statutes in most other developed nations). These "accredited investors" are thought to be sophisticated and experienced in financial matters, therefore, able to withstand the risk of this type of investment.

If the company's individual investors were to lodge enough serious complaints with the SEC, the company's shareholder situation could come under a higher level of legal scrutiny that could trigger an investigation. The SEC would find that the company had no documents showing that the individual shareholders were accredited investors under the regulations. The regulator could decide that the prior actions of the founders and the decisions of the board had been prejudicial to the interests of the minority investors. As a remedy to protect the rights of the hundreds of current shareholders, the SEC could compel the conversion of the company's registration status from a privately held corporation to a publicly traded corporation.

This re-registration would subject the company to all of the burdensome regulations required of publicly traded corporations, such as detailed regulatory disclosure filings and public announcements of financial results as well as strategic decisions, risks, and threats. It would no longer be technically possible for the executives to call the sale of any future shares an official "IPO." Furthermore, the board of directors would have a difficulty in restricting owners from selling their shares in the over-the-counter (OTC) market, which could even lead to an unwelcome takeover by a competitor or corporate raider. This could put the company in a much worse situation with the burdensome costs of regulatory compliance but without the significant benefits of increased financial capital and brand promotional recognition normally gained by an IPO. 


\section{What Happened in Reality?}

(To be communicated to the board seminar participants after they have discussed the case in small groups and have presented the results to the other groups)

The solution for keeping the shareholders satisfied so that the company could remain private until it could reach its objectives was found, apparently contradictorily, in the public company process realm. The finance team added standard "investor relations" regulated processes to its responsibilities. Most start-ups are so closely held in ownership, and that the large investors backing the company are represented directly by one or more of the elected directors on the board. Directors are direct recipients of management-supplied information. MSI includes financial reports and statements and formal board meeting discussions on regular schedules. Directors also communicate with each other and with management on an ad hoc basis. Just as the company's software engineers were recognized innovators in IT communications technology for their global customers, the finance director designed and implemented a measuredly transparent investor communications regime for the company, in order to engender trust with hundreds of disperse company shareholders.

- After each fiscal quarter, an investor packet was produced for board approval. The finance director supplied a commentary to the financial statements, summarizing the reasons for the results, especially in the categories of sales revenues, operating profits or losses, other gains or losses, cash flow, and business investments. The standard financial statements including profit and loss, balance sheet, changes in equity, and cash flow were also prepared for the packet. The approved packet was mailed by post to all of the shareholders.

- The finance director also took phone calls from individual investors and from the advisor to the shareholders of the former UK unit trust. The finance director had to be careful to restrict answers to questions related only to the company's quarterly packet and other publicly available disclosures and information about the company. Discussing any other items could have risked favoring or prejudicing one owner over the others, or information not yet approved by the board of directors could have been inadvertently disclosed.

- Each year, all investors were invited by the board of directors to the annual meeting of shareholders at the company headquarters. They were allowed to vote on any items under their rights as shareholders, either in person, by mail, or by proxy.

In the mid-1990s, the new management successfully raised an offer for a few million US\$ in a private equity placement from a venture capital firm from the Northeast USA. The board of directors informed all shareholders of the impending issuance of this new tranche of shares and of the implications of dilution that this sale would have to their overall ownership. All shareholders were solicited to vote, and they overwhelmingly approved the transaction.

\section{Does This Company Still Exist Today?}

The company successfully achieved its IPO during the late 1990s dot-com stock market bubble, in the period former US Federal Reserve Chairman Alan Greenspan described as "irrational exuberance." During the subsequent downward technology 
stock price correction, the company was acquired by a midsize publicly traded software company and absorbed into one of its many business divisions. And just a few years after that, the acquiring company was itself acquired by one of the world's top ten software giants who had an unfavorable industry reputation of purchasing rival companies, severely cutting employees and costs of new innovation, and then charging customers higher rates for software maintenance service for many years that followed.

\section{What Can We Learn from This Case?}

1. The board of director's and management's responsibilities to owners (shareholders) should be given top consideration at every stage of development of a company. Investors in companies have similar rights, needs, and expectations for fair treatment and transparency whether the company is a small private company or a major global corporation.

2. The currently favored trend of soliciting "friends and family" in an early round of start-up financing could be a two-edged sword. If everything goes smoothly, startup founders can keep their friends and family relationships intact. If business goes awry, they may not only lose face with their closest allies; they may also find themselves being called to account facing federal government regulators. Having more individual shareholders increases the potential for some to become angry investors registering complaints with the SEC or even filing a securities lawsuit against the board of directors and executive officers.

3. When a company goes through a crisis, especially when that crisis is self-inflicted at the management board or supervisory board level, many unexpected and unwanted repercussions can follow. This could be called "corporate karma." The company had not solicited any of their owners illegally. Nevertheless, the company now had hundreds of individual investors, and there was no way to know whether or not any of them were accredited investors at the point of time they had acquired their shares. The risk was high because the nature and severity of the company's problems could be linked to the same founders who had also originally solicited investments from the unit trust and the employees.

4. The SEC generally defines "penny stocks" as shares in a company that trade for less than $\$ 5$ in the OTC market, i.e., not in a registered stock exchange. Penny stocks have had a long history of investment fraud and abuse. During the period that the company was founded and restarted, there was a particularly significant level of fraudulent activity regarding sales and market price manipulation of penny stock companies that also involved organized crime. This led to new legislation enacted in the USA, the "Securities Enforcement Remedies and Penny Stock Reform Act of 1990." The SEC also allows that penny stocks could apply to certain private companies whose shares are not intended to be traded, which definitely could have included the company of this case study.

5. Enlisting new leaders to take over a turnaround situation will not be able to shield the company from difficult surprises carried over from past sins. Mature, experienced executives and board members with cool heads, warm hearts, and working hands will need to be called upon to avoid panic, build consensus, and construct solutions to the serious problems that will arise. 
Open Access This chapter is licensed under the terms of the Creative Commons Attribution 4.0 International License (http://creativecommons.org/licenses/by/4.0/), which permits use, sharing, adaptation, distribution and reproduction in any medium or format, as long as you give appropriate credit to the original author(s) and the source, provide a link to the Creative Commons licence and indicate if changes were made.

The images or other third party material in this chapter are included in the chapter's Creative Commons licence, unless indicated otherwise in a credit line to the material. If material is not included in the chapter's Creative Commons licence and your intended use is not permitted by statutory regulation or exceeds the permitted use, you will need to obtain permission directly from the copyright holder.

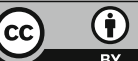

